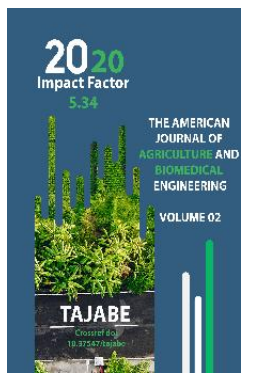

Journal Website: http://usajournalshub.c om/index,php/tajabe

Copyright: Original content from this work may be used under the terms of the creative commons attributes 4.0 licence.

\section{Using Microbial Preparations Against Moroccan Locust (Dociostaurus Maroccanus Thunb., 1815) In Uzbekistan}

\author{
Tufliyev N.Kh. \\ Department Of Plant Protection, Tashkent State Agrarian University, Uzbekistan.
}

\author{
Abdalyazov N.A. \\ Academy Of Mamun, Science Academy Of The Republic Of Uzbekistan, Uzbekistan. \\ Akhmedjanov Sh. \\ Department Of Plant Protection, Tashkent State Agrarian University, Uzbekistan. \\ Amirov I.B. \\ Institute Of Zoology, Science Academy Of The Republic Of Uzbekistan, Uzbekistan. \\ Medetov M.J. \\ Institute Of Zoology, Science Academy Of The Republic Of Uzbekistan, Uzbekistan.
}

\title{
ABSTRACT
}

The article about the results of the experiment, which provided to definite of biological efficacy the microbial preparations - Kiloca, Fast Kiloca, based on the fungi metarrhizium anisoplia. The experiments carried out in laboratory condition to control of Maroccan locust (daciastaurus moroccanus Thunb.) where collected from pastures of Guzar and Nishan provinces of Kashkhadarya region of the Republic of Uzbekistan.

\section{KEYWORDS}

locust crops, biopesticides, microbiopesticides, moroccan.

\section{INTRODUCTION}

In the world, harmful locusts require constant attention from industry experts. Only in the countries of the Caucasus and Central Asia, failure to control harmful herd locusts, such as Moroccan, Italian and Asian locusts, by causing damage to pasture lands on an area of more than 25 million hectares, as well as agricultural crops, leads to loss of received from them products. As a result, more than 20 million people could left without agricultural products.

The development and improvement of evidence-based control measures against these pests and their timely implementation in foothill, pasture and steppe zones is one of the most important tasks of almost all countries of the world where locusts are 
common. In particular, studies have conducted in the United States, Europe, Australia, China, the CIS countries, Africa and various regions of other Asian countries where harmful locusts are common. However, studies on the creation of conditions for microbiological control of harmful locusts, the creation of a complex for the application of modern methods and means against them, the determination of the causes of the spread of non-herd locust crops around crops, and the development of effective control measures against them.

In the Republic, some types of harmful locusts are dangerous not only for pasture plants, but also for all crops. To constantly ensure, the needs of the population in dairy and meat products, an important task is to protect the vegetation of foothill, pasture and steppe zones from harmful locusts. The Development Strategy of the Republic of Uzbekistan in 20172021 noted that the priority tasks of agriculture are "... the development and implementation of measures to protect plants from diseases and pests." In this regard, in order to prevent mass reproduction and create a danger to crops, it is necessary to identify the main harmful species of locusts found in the foothills, pasture and steppe zones, study the features of their development, as well as create and implement a set of effective, environmentally friendly measures and means.

Currently, the focus in the control against pest locusts is the use and spread of ecologically safe biopesticides. In particular, it has been studied that the microbiopesticides of Green Guard SC Premium against moroccan locust and Italian locust (Calliptamus italicus L.) has a biological effect controlled near $80.0 \%$, this is effectively score in Uzbekistan and Georgia $[1,4,5]$.

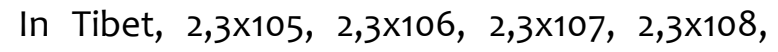
$2,3 \times 109$ colonization of pests, when controlled Metarrhizium anisopliae against Locusta migratoria tibetensis, it was $71 \%-100 \%$ effective $[4,6]$.

\section{MATERIAL AND METHODS}

One such biopesticide is Xin Jiang MOER Chemscaence Co., China. Ltd., Kiloca m.sus.k based on Metarrhizium anisopliae fungi produced by Consumption of biopesticide ( 1 : 20x108) $1.0-1.5$ / / ha as well as in order to increase the initial effect of this biopesticide, the chemical-acting compound betacypermetrhin belongs to the group of pyrethroids of the Metarrhizium anisopliae fungus $(1: 20 \times 108)+1 \%$ Fast Kiloca o.sc.k. the experiments were carried out to study the biological effectiveness of biopesticides in laboratory conditions against Moroccan locust, which produces a pile of the main pest locusts spread in the Republic in 2013 in the amount of $1,0 \mathrm{l} / \mathrm{ha}$.

The study of the biological efficacy of biopreparates used in experiments was calculated in [2] method and make a dispersion analysis of the results of the conducted experiments by the method [3].

\section{RESULTS AND DISCUSSION}

Our experiments were conducted with the creation of natural conditions for locusts in specially made boxes. On average, each of the box put nymph of healthy II-III young Moroccan locusts of 30-40 (1-picture). 


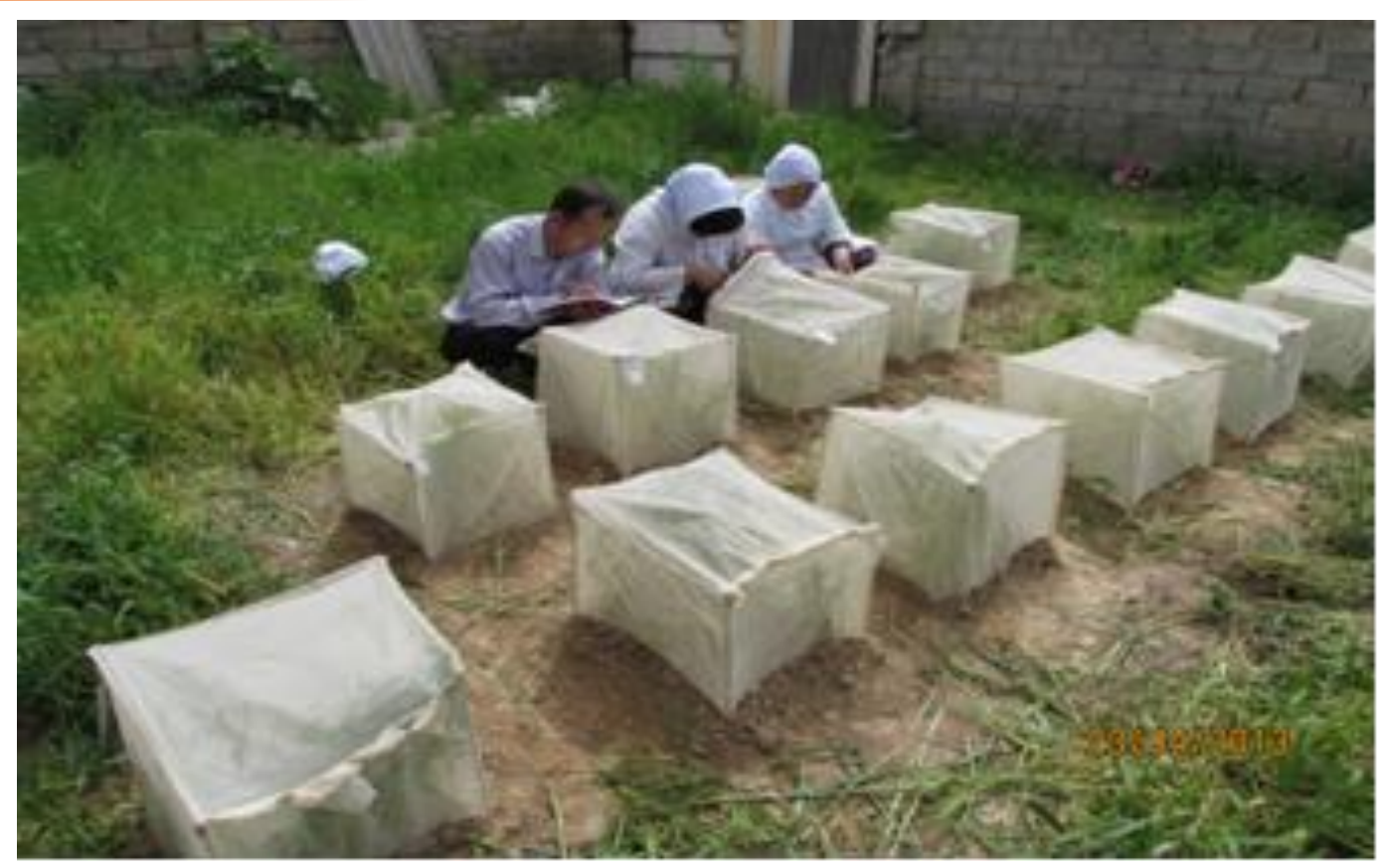

1-picture. Special boxes were used for laboratory experiments.

The nymph of this locust were collected from the Guzor and Nishon districts of Kashkadarya region.

For the template, the Green Guard SC$0,5 \mathrm{l} /$ ha biopesticide was used (2-table). During the accounting period of our experiments, temperatures were also monitored and the average temperature was 28-300C. In experiments with Kiloca biopesticide- spreading on $1,0 \mathrm{I} / \mathrm{m}$ in the 2 day of the calculation observation in the variant used in $52,1 \%$, If on 4 day gave $55,3 \%$, on 6 day $62,5 \%$, on 8 day $69,7 \%$, on 21 day $83,4 \%$ biological effect, in the variant used to spend $1,5 \mathrm{l} / \mathrm{ha}$, the calculation gave a biological effect of $64,6 \%$ on the 2 day of observation, $71,8 \%$ on the 4 day, $74,0 \%$ on the 6 day, $75,0 \%$ on In the variant applied to the Green Guard SC-0,5 I/ha, it was found that the calculation gave a biological effect of $29,6 \%$ on the 2 day of observation, $36 \%$ on the 4 day, $41,0 \%$ on the 6 day, $45,7 \%$ on the 8 day, and $92,0 \%$ on the 32 day.

1-table

Kiloca sc. (Metarrhizium anisopliae) biological efficacy of biopesticide against Moroccan locust nymph. (Laboratory experience, hand sprayer (120 I/ha), 25.04.2013) 
The American Journal of Agriculture And Boimedical Engineering (ISSN - 2689-1018)

Published: August 30, 2020 | Pages: 138-142

Doi: https://doi.org/10.37547/tajabe/Volume02Issueo8-16

\begin{tabular}{|c|c|c|c|c|c|c|c|c|c|c|c|c|}
\hline \multirow{3}{*}{ Options } & \multirow{3}{*}{$\begin{array}{c}\text { Prepara- } \\
\text { tion } \\
\text { consumpti } \\
\text { on norm } 1 \\
/ \text { ha }\end{array}$} & \multicolumn{11}{|c|}{ Number of nymph. } \\
\hline & & \multirow{2}{*}{$\begin{array}{c}\text { Processi } \\
\text { ng } \\
\text { up to } \\
25.04 .13\end{array}$} & \multicolumn{10}{|c|}{ Observations after treatment with Biopreparat, $\mathrm{n}$ days after } \\
\hline & & & $\begin{array}{l}27.04 . \\
2 \text { days }\end{array}$ & $\begin{array}{c}29.04 . \\
4 \mathrm{~d} .\end{array}$ & $\begin{array}{l}01.05 . \\
6 \mathrm{~d} .\end{array}$ & $\begin{array}{l}03.05 \\
8 \mathrm{~d} .\end{array}$ & $\begin{array}{c}05.05 . \\
10 \mathrm{~d} .\end{array}$ & $\begin{array}{l}07.05 \\
12 \mathrm{~d} .\end{array}$ & $\begin{array}{l}10.05 \\
15 \mathrm{~d} .\end{array}$ & $\begin{array}{l}14.05 \\
19 \mathrm{~d} .\end{array}$ & $\begin{array}{l}21.05 . \\
26 \mathrm{~d} .\end{array}$ & $\begin{array}{l}27.05 \\
32 \mathrm{~d} .\end{array}$ \\
\hline Kiloca (Metarrhizium) & 1,0 & 32,0 & 15,3 & 14,3 & 12,0 & 9,7 & 9,3 & 9,3 & 8,3 & 8,3 & 5,3 & 3,7 \\
\hline Kiloca (Metarrhizium) & 1,5 & 32,0 & 11,3 & 9,0 & 8,3 & 8,0 & 7,7 & 7,3 & 5,7 & 5,7 & 3,7 & 1,0 \\
\hline $\begin{array}{c}\text { Green Guard SC } \\
\text { (template) }\end{array}$ & 0,5 & 30,0 & 21,1 & 19,2 & 17,7 & 16,3 & 12,5 & 12,0 & 11,7 & 10,0 & 5,7 & 2,4 \\
\hline Control & - & 30,0 & 29,0 & 29,0 & 28,7 & 28,3 & 27,7 & 26,7 & 25,3 & 24,7 & 22,7 & 19,0 \\
\hline \multicolumn{13}{|c|}{ biological efficiency, \% } \\
\hline Kiloca (Metarrhizium) & 1,0 & 32,0 & 52,1 & 55,3 & 62,5 & 69,7 & 70,9 & 70,9 & 74,0 & 74,0 & 83,4 & 88,4 \\
\hline Kiloca (Metarrhizium) & 1,5 & 32,0 & 64,6 & 71,8 & 74,0 & 75,0 & 75,9 & 77,1 & 82,1 & 82,1 & 88,4 & 96,8 \\
\hline $\begin{array}{c}\text { Green Guard SC } \\
\text { (template) }\end{array}$ & 0,5 & 30,0 & 29,6 & 36,0 & 41,0 & 45,7 & 58,3 & 60,0 & 61,0 & 66,7 & 81,0 & 92,0 \\
\hline Control & - & - & - & - & - & - & - & - & - & - & - & - \\
\hline
\end{tabular}

2-table.

Fast Kiloca m.shut up.the G. (Metarrhizium anisopliae $+1 \%$ betacypermetrhin) biopesticide to moroccan locust's nymph

injection biological efficiency. (Laboratory experience, hand sprayer (120 l/ha), 25.04.2013)

\begin{tabular}{|c|c|c|c|c|c|c|c|c|c|c|c|c|}
\hline \multirow{3}{*}{ Options } & \multirow{3}{*}{$\begin{array}{c}\text { Prepara- } \\
\text { tion } \\
\text { consumpti } \\
\text { on norm } 1 \\
/ \mathrm{ha}\end{array}$} & \multicolumn{11}{|c|}{ Number of nymph. } \\
\hline & & \multirow{2}{*}{$\begin{array}{l}\text { Proces- } \\
\text { sing } \\
\text { up to } \\
25.04 .13\end{array}$} & \multicolumn{10}{|c|}{ Observations after treatment with Biopreparat, $\mathrm{n}$ days after } \\
\hline & & & $\begin{array}{c}27.04 . \\
2 \mathrm{~d}\end{array}$ & $\begin{array}{c}29.04 \\
4 \mathrm{~d}\end{array}$ & $\begin{array}{c}01.05 . \\
6 \mathrm{~d}\end{array}$ & $\begin{array}{c}03.05 \\
8 \mathrm{~d}\end{array}$ & $\begin{array}{c}05.05 . \\
10 \mathrm{~d}\end{array}$ & $\begin{array}{l}07.05 \\
12 \mathrm{~d}\end{array}$ & $\begin{array}{l}10.05 \\
15 \mathrm{~d}\end{array}$ & $\begin{array}{r}14.05 \\
19 \mathrm{~d}\end{array}$ & $\begin{array}{c}21.05 \\
26 \mathrm{~d}\end{array}$ & $\begin{array}{r}27.05 \\
32 \mathrm{~d}\end{array}$ \\
\hline $\begin{array}{c}\text { Fast Kiloca } \\
\text { (Metarrhizium + } \\
1 \% \text { beta cypermetrhin) }\end{array}$ & 1,0 & 36,7 & 3,3 & 2,3 & 2,3 & 2,3 & 2,0 & 2,0 & 1,3 & 1,3 & 0,7 & 0,0 \\
\hline $\begin{array}{c}\text { Green Guard SC } \\
\text { (template) }\end{array}$ & 0,5 & 30,0 & 22,0 & 19,3 & 18,0 & 16,4 & 13,3 & 12,0 & 11,3 & 10,7 & 5,8 & 2,7 \\
\hline Control & - & 30,0 & 30,0 & 29,6 & 29,0 & 28,6 & 28,0 & 27,3 & 26,7 & 25,0 & 23,6 & 21,0 \\
\hline \multicolumn{13}{|c|}{ biological efficiency, $\%$} \\
\hline $\begin{array}{c}\text { Fast Kiloca } \\
\text { (Metarrhizium+ } \\
1 \% \text { beta cypermetrhin) }\end{array}$ & 1,0 & 36,7 & 91,0 & 93,7 & 93,7 & 93,7 & 94,5 & 94,5 & 96,4 & 96,4 & 98,0 & 100 \\
\hline $\begin{array}{c}\text { Green Guard SC } \\
\text { (template) }\end{array}$ & 0,5 & 30,0 & 26,6 & 35,6 & 40,0 & 45,3 & 55,6 & 60,0 & 62,3 & 64,3 & 80,6 & 91,0 \\
\hline Control & - & - & - & - & - & - & - & - & - & - & - & - \\
\hline
\end{tabular}


As well as, in experiments with biopesticide treated with a chemical compound Fast Kiloca $1,5 \mathrm{I} / \mathrm{ha}$ biopesticide, the calculation was made on 2 days of observation $91,0 \%$, on 4 days $93,7 \%$, on $6,8,10$ days $93,7 \%-93,7 \%-94,5 \%$ biological efficiency, it gained $26 \%$ biological efficiency in 98,0 days, $32 \%$ in 100 days. The Green Guard SC-0,5 I/ha variant used in variant was found to have a biological effect of $26,6 \%$ on the 2 day of the follow-up, 35,6\% on the 4 day, $40,0 \%$ on the 6 day, and $91,0 \%$ on the 32 day of the follow-up (2- table). In both experiments, locust's nymph did not controlled, which were put under control, was not observed.

\section{CONCLUSIONS}

1. According to the results of the experiment, the maximum biological effect of using Kiloca biopesticide at 1.0l / ha in the control against Moroccan locusts was $88.4 \%$, with the highest biological efficiency of $1.5 \mathrm{I} / \mathrm{ha}$. , $8 \%$.

2. Fast Kiloca also records the highest $100.0 \%$ bio-efficiency of microbiological and chemical pesticides at $1.0 \mathrm{l} / \mathrm{d}$ to accelerate initial effects to improve microbial biopesticides effects.

3. At the expense of these Kiloca-1.0-1.5 I/ ha and Fast Kiloca-1.0 I / L, it is recommended to use these biopreparations against common locust for the purpose of saving ecological environment.

\section{REFERENCES}

1. Gapparov F.A., Nurzhanov A.A., Tufliyev N.Kh., Agzamova Kh.K., Medetov M. New biological preparations against pests in Uzbekistan. // Journal of Plant Protection and Quarantine. - Moscow, 2013 - No. 6. p. 28.

2. Dospekhov B.A. Field experiment technique. - M .: Agropromizdat, 1985 .-$432 \mathrm{p}$.

3. Kurdyukov V.V., Khodjaev Sh.T., Gapparov F.A. Harmful locusts // Guidelines for testing insecticides, acaricides, biologically active substances and fungicides. -Tashkent: Uzinformagroprom, 1994. - p. 18-20.

4. Tufliev N.Kh. Creation of a complex for the fight against harmful locusts in the foothill, pasture and steppe zones of Uzbekistan, author's abstract of the dissertation of a doctor (dsc) of agricultural sciences. 06.01.09. - Tashkent, 2019 -- 69 p. (Uzbek, Russian language).5.Hunter D.M., Latchininsky A.V., Abashidze E., Gapparov F.A., Nurzhanov A.A., Tufliev N.Kh., Medetov M.Z. The efficacy of Metarhizium acridum against nymphs of the Italian locust, Calliptamus italicus (Orthoptera:Acrididae) in Uzbekistan and Georgia. //Journal of Orthoptera Research. - USA, 2016. - Volume 25(2): P. 61-65.

5. Sali, Y.S., Nong, X.Q., Wang, W.F., Sidike, AL.M., Zhang, Z.H. Evaluation for Virulence and Potential Application of Metarhizium Strains against Tibet Migratory Locusts: Locusta migratoria tibetensis Chen (Orthoptera, Acridoidea). I 11th international Congress of Orthopterology, Orthoptera in scientific progress and human culture Abstract \& Program. 11th-15th, Aug, 2013. Kunming, China. - P. 168. 